\title{
Mutation Induction of Dendrobium 'Earsakul' Using Sodium Azide
}

\author{
Anakkaorn Wannajindaporn, Chitpan Kativat, \\ and Piyada Alisha Tantasawat ${ }^{1}$ \\ School of Crop Production Technology, Suranaree University of Technology, \\ 111 University Avenue, Muang District, Nakhon Ratchasima 30000, \\ Thailand
}

Additional index words. DNA marker, genetic variation, ISSR, morphology, mutation, orchid

Abstract. Dendrobium 'Earsakul' is an important commercial orchid in Thailand. Breeding new Dendrobium varieties for improved quality and yield is crucial. The objectives of this research were to perform in vitro mutagenesis of Dendrobium 'Earsakul' protocorm-like bodies (PLBs) using sodium azide $\left(\mathrm{NaN}_{3}\right)$ and to select and evaluate the putative mutants using morphological characters, molecular markers, and the cytological method. The percentages of mortality of PLBs increased as concentrations of $\mathrm{NaN}_{3}$ increased. At 2 weeks, the lethal dose $30\left(\mathrm{LD}_{30}\right)$ and $\mathrm{LD}_{50}$ were obtained with 0.1 and $0.5 \mathrm{~mm} \mathrm{NaN}_{3}$, respectively. These two $\mathrm{NaN}_{3}$ concentrations were used for in vitro mutagenesis with reverse osmosis water (ROW; control 1) and $0 \mathrm{~mm} \mathrm{NaN}_{3}$ (control 2) as controls. After the plants were cultured for 6 months, morphological differentiation was observed in some putative mutants: reduced height, higher numbers of nodes, reduced node length, shorter and thicker leaves, and shorter and fewer roots, compared with controls. When genetic profiles of 24 putative mutants were compared with controls, altered DNA profiles were found in 20 of 24 putative mutants $(83.33 \%)$. Sixty-three polymorphic bands were produced from a total of 181 bands (34.81\%) amplified by 10 polymorphic intersimple sequence repeat (ISSR) primers. When genetic diversity and relatedness, which were evaluated by ISSR analysis, and morphological characters were compared, the two markers were found to be uncorrelated. ISSR had a higher mutant differentiation capability than the morphological characters, indicating its higher efficiency. The chromosome numbers were similar in putative mutants and controls $(2 n=2 x=24)$, suggesting that neither of the concentrations of $\mathrm{NaN}_{3}$ had any effect on the chromosome numbers in this experiment. These results indicate that $\mathrm{NaN}_{3}$ can be used effectively to mutagenize Dendrobium 'Earsakul' PLBs, and ISSR is a powerful tool for the identification of mutants. Chemical name: sodium azide $\left(\mathrm{NaN}_{3}\right)$; reverse osmosis water $(\mathrm{ROW})$.

Dendrobium 'Earsakul' is one of the most important commercial orchids in Thailand, which is one of the world's largest orchid producers and exporters (Luan et al., 2006). At present, new Dendrobium 'Earsakul' varieties with improved flower quality and yield as well as unique floral characteristics are increasingly in demand both domestically and internationally. Therefore, breeding new Dendrobium varieties has been performed using various methods, e.g., conventional breeding (hybridization and selection) and genetic engineering. In addition, mutation breeding is an efficient alternative for genetic improvement of orchids. It can generate phenotypic variations in both vegetative and reproductive characteristics (shape, color, form, and size of flowers and/or leaves); yield;

Received for publication 11 May 2016. Accepted for publication 23 Aug. 2016.

This work was supported by the Office of the Higher Education Commission under NRU project of Thailand, and grants from Thailand Research Fund and Suranaree University of Technology, Thailand.

We are very grateful to Peter Charles Bint for the critical reading of this manuscript.

${ }^{1}$ Corresponding author. E-mail: piyada@sut.ac.th. tolerance; and resistance to environment, diseases, and insect pests (Novak and Brunner, 1992). The advantage of this method is the possibility of modifying one or two characters without changing the majority of phenotypes (Al-Qurainy and Khan, 2009). Furthermore, it can also be used together with tissue culture (in vitro mutagenesis), which is an important tool for mutant production and thus speeds up the breeding program (Khan et al., 2009). Therefore, it has been used successfully in several plants including Dendrobium (Khatri et al., 2011; Khosravi et al., 2009; Kumar et al., 2011; Mostafa and Alfrmawy, 2011).

Mutations can be induced by either radiation or chemical mutagens. The most commonly used chemical mutagens which do not require expensive equipments are ethyl methane sulphonate, pronamide, ethyl nitroso urea, and $\mathrm{NaN}_{3}$ (Wannajindaporn et al., 2014). $\mathrm{NaN}_{3}$ is a powerful chemical mutagen that causes point mutation (transitions and transversions), especially $\mathrm{AT}$ to $\mathrm{CG}$ that can result in amino acid changes, modifying the function of proteins, and altering plant phenotypes. It also induces chromosome aberrations, predominantly translocations, lagging chromosomes, bridges, sticky chromosomes, and polyploidization (Al-Qurainy and Khan,
2009; Klášterská et al., 1976; Wannajindaporn et al., 2014). The mechanism of $\mathrm{NaN}_{3}$ is mediated through the production of organic metabolite of azide compound [L-azidoalanine; $\mathrm{N}_{3}-\mathrm{CH}_{2}-\mathrm{CH}(\mathrm{NH})_{2}-\mathrm{COOH}$ (Al-Qurainy and Khan, 2009). The metabolite enters into the nucleus, interacts with DNA and creates point mutation in the genome (Srivastava et al., 2011). $\mathrm{NaN}_{3}$ has been used for enhancement of yield and quality traits of several crops such as peanuts (Arachis hypogaea L.) (Mensah and Obadoni, 2007), broad bean (Vicia faba L.) (Qari, 2008), mungbean (Vigna radiata L.) (Khan et al., 2004), common bean (Phaseolus vulgaris L.) (Jeng et al., 2010), cowpea (Vigna unguiculata L. Walp. ssp. unguiculata) (Mshembula et al., 2012), pea (Pisum sativum L.) (Türkan et al., 2006), rice (Oryza sativa L.) (Jeng et al., 2006; Suzuki et al., 2008), barley (Hordeum vulgare L.) (Olsen et al., 1993; Sideris et al., 2004), sorghum (Sorghum bicolor L. Moench) (Dahot et al., 2011), tomato (Solanum lycopersicum L.) (Adebola, 2013), and rocket (Eruca sativa) (Al-Qurainy, 2009). In sunflowers (Helianthus annuus L.), mutagenic $\mathrm{NaN}_{3}$ produced mutants whose seeds contain 35\% stearic acid (Škorić et al., 2008). In bluebell (Browallia speciosa), $\mathrm{NaN}_{3}$ induced changes in flower color, flower shape, and leaf form (El-Mokadem and Mostafa, 2014). Whereas, in the terrestrial orchid (Spathoglottis plicata), $\mathrm{NaN}_{3}$ induced strikingly attractive flower color modifications (Roy and Biswas, 2005). However, several factors, e.g., concentration, duration, $\mathrm{pH}$, pre- and posttreatment, and temperature influence the effects of $\mathrm{NaN}_{3}$ for inducing mutations. Therefore, optimal conditions need to be determined for individual plants and tissues.

The effects of mutagens can be monitored via changes in morphological characters, genetic profiles, and chromosome numbers. The changes in morphological characters are traditionally used for the selection of mutants; however, this method is time consuming and unreliable because of environmental and pleiotropic effects. In addition, mutations of many plant genes may not lead to easily identifiable phenotypes. Therefore, direct selection based on DNA markers circumvents these limitations, increasing the efficiency as well as reducing the cost and time of selection. Several mutants and somaclonal variants have been identified by many DNA markers including amplified fragment length polymorphism, restriction fragment length polymorphism, random amplified polymorphic DNA, simple sequence repeat, and ISSR (Barakat et al., 2010; Bidabadi et al., 2012; Khawale et al., 2006; Khosravi et al., 2009; Kuchma et al., 2011; Kumar et al., 2011; Mostafa and Alfrmawy, 2011; Santos et al., 2008; Yoocha et al., 2006).

ISSRs are randomly distributed throughout the genome, allowing the detection of multiple loci simultaneously, highly polymorphic, reliable, codominant and can be widely applied in all organisms without requiring prior sequence information (Reddy et al., 2002). ISSR markers have been used in many crop plants such as mustard (Brassica rapa ssp. yellow sarson) (Kumar et al., 2011), banana (Musa spp. L.) 
(Khatri et al., 2011), Indian teak (Tectona grandis L.f.) (Ansari et al., 2012), yard long bean ( $V$. unguiculata spp. sesquipedalis) (Tantasawat et al., 2010a), and mungbean (Tantasawat et al., 2010b). In addition, they have been used in several ornamental plants such as Madagascar periwinkle (Catharanthus roseus (L.) G. Don) (Shaw et al., 2009), dogwood (Cornus spp.) (Shi et al., 2010), chrysanthemum (Chrysanthemum indicum L.) (Palai and Rout, 2011), lily (Lilium longiflorum) (Xi et al., 2012), as well as several orchids including foxtail orchid (Rhynchostylis retusa) (Parab and Krishnan, 2008), spring orchid (Cymbidium goeringii) (Wang et al., 2009b; Yao et al., 2007), jewel orchid (Anoectochilus formosanus Hayata) (Zhang et al., 2010), and Dendrobium (Wang et al., 2009a; Wannajindaporn et al., 2014). Mutations from deletions/duplications or nucleotide changes at the ISSR primer binding sites lead to altered patterns of amplified DNA fragments and allow efficient mutant selections. Its multilocus nature as well as reproducibility and simplicity make it particularly attractive for analyzing a number of mutants with limited genetic changes.

Moreover, mutations can also be identified by the changes in chromosome structure and numbers via the cytological method. This method has been used in several Dendrobium such as golden-bow orchid (Dendrobium chrysotoxum) (Atichart, 2013), pigeon orchid (Dendrobium crumenatum Sw.) (Meesawat et al., 2008), and Dendrobium draconis Rchb. f. (Petchang, 2010). In this study, we determined the optimal conditions for $\mathrm{NaN}_{3}$ induced in vitro mutagenesis of Dendrobium 'Earsakul' PLBs and identified mutants based on morphological characters, ISSR markers and the cytological method.

\section{Materials and Methods}

Plant materials. PLBs from clonal propagation of Dendrobium 'Earsakul' were treated with ROW (control 1) and 0 (control 2), $0.1,0.5,1.0,1.5,2.0,3.0$, and $4.0 \mathrm{~mm}$ $\mathrm{NaN}_{3}$ in $100 \mathrm{~mm}$ citrate buffer ( $\left.\mathrm{pH} 5\right)$, for $1 \mathrm{~h}$ (120 PLBs/treatment). After the mutagen treatments, they were transferred to VW 1 medium (Tantasawat et al., 2015) and maintained at $27 \pm 2{ }^{\circ} \mathrm{C}$ under a 16 -h photoperiod provided by cool-white fluorescent tubes at a photosynthetic photon flux density of $100 \mu \mathrm{mol} \cdot \mathrm{m}^{-2} \cdot \mathrm{s}^{-1}$. Mortality of PLBs was recorded at $3 \mathrm{~d}, 1$ and 2 weeks. $\mathrm{NaN}_{3}$ concentrations causing $30 \%$ and $50 \%$ mortality $\left(\mathrm{LD}_{30}\right.$ and $\left.\mathrm{LD}_{50}\right)$ were determined from the LD response curve. Twenty-four putative mutants were randomly selected from $\mathrm{LD}_{30}$ (M1 to M12) and $\mathrm{LD}_{50}$ (M13 to M24) treatments. Ten nonmutagenized controls (C1 to $\mathrm{C} 10)$ were randomly selected from control 1 (C1 to $\mathrm{C} 5$ ) and control 2 (C6 to $\mathrm{C} 10)$.

Analysis of morphological characters. Morphological analysis of 24 putative mutants and 10 controls were performed at 6 months. Plant characteristics (height, numbers of nodes, and node length), leaf characteristics (numbers of leaves, leaf length, leaf width, leaf color, leaf thickness, and leaf arrangement), and root characteristics (numbers of roots and root length) were evaluated. The height was measured from the base to the top of the pseudobulbs. The numbers of nodes were measured by counting manually all the nodes of the pseudobulbs. The node length was calculated from the plant height/numbers of nodes. The numbers of leaves were counted manually. The leaf length was measured from the base to the longest point and the leaf width was measured from the widest part of the first leaves from the top. The leaf color, leaf thickness, and leaf arrangement were visually observed. The numbers of roots were manually counted. The root length was measured from the base to the longest point of the longest roots. One way analysis of variance and Duncan's multiple range test were used to evaluate the differences in these parameters between treatments with a completely randomized design using SPSS version 14.0 (Levesque and SPSS Inc., 2006). Morphological alterations were identified using the following criteria: reduced height was 0 to $1.20 \mathrm{~cm}$, normal height was $>1.20 \mathrm{~cm}$; reduced node length was 0 to $0.30 \mathrm{~cm}$, normal node was $>0.30 \mathrm{~cm}$; higher numbers of nodes were higher than five nodes, normal numbers of nodes were 1 to 5 nodes; shorter leaves were 0 to $1.50 \mathrm{~cm}$, normal leaves were $>1.50 \mathrm{~cm}$; thicker leaves were visibly thicker and darker green, normal leaves were thin and normal green; shorter roots were 0 to $1 \mathrm{~cm}$, normal roots were $>1 \mathrm{~cm}$; fewer roots were 1 to 2 roots, normal roots were $>2$ roots. Recorded morphological alteration data were coded as 0 or 1 for their absence or presence, respectively.

DNA isolation. Young leaves were freshly harvested from 24 putative mutants and 10 controls and rapidly frozen in liquid $\mathrm{N}_{2}$. DNA extraction was performed by the cetyltrimethylammonium bromide method modified from Zhang et al. (2009). DNA was quantified by spectrophotometry using a ND-1000 spectrophotometer (NanoDrop Technologies, Inc., Wilmington, DE), and the final concentrations were adjusted to $25 \mathrm{ng} \cdot \mu \mathrm{L}^{-1}$ for use in the ISSR analysis.

ISSR analysis. Twelve ISSR primers homologous to microsatellite repeats and containing additional selective anchor nucleotides that were developed from the University of British Columbia and which have been used successfully in Dendrobium (Wannajindaporn et al., 2014) were chosen for the analysis. The polymerase chain reaction (PCR) was modified from Baloch et al. (2010) and Brown-Guedira et al. (2000). Each $20 \mu \mathrm{L}$ PCR mix contained 50 ng genomic DNA template, $10 \times$ buffer $[75 \mathrm{~mm}$ Tris- $\mathrm{HCl}, \mathrm{pH}$ 9.0, $\left.50 \mathrm{~mm} \mathrm{KCl}, 20 \mathrm{~mm}\left(\mathrm{NH}_{4}\right)_{2} \mathrm{SO}_{4}\right], 25 \mathrm{~mm}$ $\mathrm{MgCl}_{2}, 2 \mathrm{~mm}$ of each dNTP, $1 \mathrm{U}$ Geneaid DNA polymerase (Geneaid Biotech Ltd., Taipei, Taiwan), and $4 \mu \mathrm{M}$ of each ISSR primer. The PCR mixes were subjected to amplification with initial denaturation at $94{ }^{\circ} \mathrm{C}$ for $5 \mathrm{~min}$; 45 cycles of denaturing at $94{ }^{\circ} \mathrm{C}$ for $45 \mathrm{~s}$, annealing at 48 to $58^{\circ} \mathrm{C}$ for $45 \mathrm{~s}$, extension

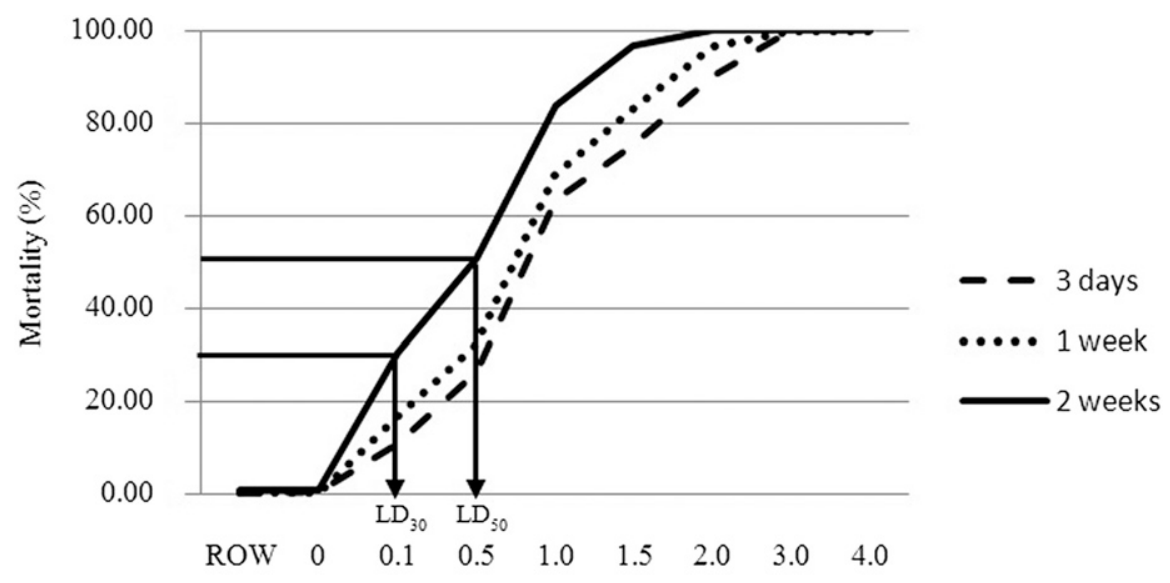

\section{$\mathrm{NaN}_{3}$ concentrations (mM)}

Fig. 1. The mortality rates of protocorm-like bodies after $3 \mathrm{~d}, 1$ and 2 weeks following $\mathrm{NaN}_{3}$ treatments and $\mathrm{LD}_{30}$ and $\mathrm{LD}_{50}$ at 2 weeks. $\mathrm{LD}=$ lethal dose; $\mathrm{NaN}_{3}=$ sodium azide; $\mathrm{ROW}=$ reverse osmosis water.

Table 1. Morphological characters of 24 putative mutants $\left[0.1 \mathrm{~mm} \mathrm{NaN}_{3}\right.$ (M1 to M12) and $0.5 \mathrm{~mm} \mathrm{NaN}_{3}$ (M13 to M24)] and 10 controls [ROW; control 1 (C1 to C5), 0 mM; control 2 (C6 to C10)] of Dendrobium 'Earsakul' at 6 months.

\begin{tabular}{lcccccccc}
\hline & $\begin{array}{c}\mathrm{Ht} \\
(\mathrm{cm})\end{array}$ & $\begin{array}{c}\text { No. of } \\
\text { nodes }\end{array}$ & $\begin{array}{c}\text { Node } \\
\text { length }(\mathrm{cm})\end{array}$ & $\begin{array}{c}\text { No. of } \\
\text { leaves }\end{array}$ & $\begin{array}{c}\text { Leaf } \\
\text { length }(\mathrm{cm})\end{array}$ & $\begin{array}{c}\text { Leaf } \\
\text { width }(\mathrm{cm})\end{array}$ & $\begin{array}{c}\text { No. of } \\
\text { roots }\end{array}$ & $\begin{array}{c}\text { Root } \\
\text { length }(\mathrm{cm})\end{array}$ \\
$\mathrm{NaN}_{3}{ }^{\mathrm{z}}(\mathrm{mm})$ & 2.25 & $2.80 \mathrm{~b}^{\mathrm{y}}$ & $0.90 \mathrm{a}$ & 7.00 & $3.64 \mathrm{a}$ & $0.60 \mathrm{a}$ & $5.75 \mathrm{a}$ & $2.80 \mathrm{a}$ \\
$\mathrm{ROW}(\mathrm{control} \mathrm{1)})$ & 1.75 & $2.40 \mathrm{~b}$ & $0.73 \mathrm{a}$ & 6.00 & $2.93 \mathrm{ab}$ & $0.60 \mathrm{a}$ & $5.50 \mathrm{a}$ & $2.94 \mathrm{a}$ \\
$0.0($ control 2) & 1.66 & $4.08 \mathrm{a}$ & $0.41 \mathrm{~b}$ & 6.92 & $2.52 \mathrm{ab}$ & $0.50 \mathrm{~b}$ & $3.33 \mathrm{~b}$ & $1.43 \mathrm{~b}$ \\
0.1 & 1.83 & $4.75 \mathrm{a}$ & $0.43 \mathrm{~b}$ & 7.25 & $2.04 \mathrm{~b}$ & $0.51 \mathrm{~b}$ & $2.75 \mathrm{~b}$ & $1.85 \mathrm{~b}$ \\
0.5 & 0.449 & 0.000 & 0.001 & 0.702 & 0.034 & 0.018 & 0.004 & 0.000 \\
Significant & &
\end{tabular}

${ }^{\mathrm{z}} \mathrm{NaN}_{3}=$ sodium azide; ROW $=$ reverse osmosis water.

${ }^{\mathrm{y}}$ Data are presented as means. Means in the same column with different letters are significantly different $(P \leq 0.05)$ based on Duncan's multiple range test. 
at $72{ }^{\circ} \mathrm{C}$ for $90 \mathrm{~s}$; and a final extension at $72{ }^{\circ} \mathrm{C}$ for $7 \mathrm{~min}$. The amplified products were revealed on $6 \%(\mathrm{w} / \mathrm{v})$ denaturing polyacrylamide gel and detected by silver nitrate according to Sambrook and Russell (2001). Molecular weights of the DNA bands were estimated using $1 \mathrm{~kb}$ plus DNA ladder (Gibco-BRL, Gaithersburg, MD) as a standard.

Data scoring, cluster, and principle coordinate analysis. The morphological alterations were coded as 0 or 1 for their absence or presence, respectively. A clearly amplified band of ISSR analysis was coded as 0 or 1 for its absence or presence, respectively. Similarity coefficients between various putative mutants and controls, in a pairwise comparison, were computed using Jaccard's genetic similarity coefficient, and the resulting similarity matrix was further analyzed using the unweighted pair group method with arithmetic average (UPGMA) clustering algorithm; the computations were carried out using NTSYSpc version 2.2 (Rohlf, 2000). The goodness of fit of the putative mutants and controls to a specific cluster in the UPGMA cluster analysis was determined by the Mantel correlation test (Mantel, 1967). A correlation value $(r)$ greater than 0.5 is considered to be statistically significant at $0.01 P$ level if the number of observed taxonomic units exceeds 15 (Lapointe and Legendre, 1992).

The correspondence between the ISSR and morphological markers were estimated by means of the Mantel matrix correspondence test (Mantel, 1967). To estimate the magnitude of the differences between dendrograms, cophenetic values were computed for each dendrogram. The NTSYSpc version 2.2 (Rohlf, 2000) was also used to perform principal coordinate analysis (PCoA) to show multiple dimensions of the distribution of the genotypes in a scatter plot (Keim et al., 1992). This multivariate approach was used to complement the information obtained from cluster analysis because it is more informative regarding distances between major groups (Tar'an et al., 2005).

Cytological analysis. The root tips $(0.5 \mathrm{~cm}$ in length) were freshly harvested from 24 putative mutants and 10 controls. The Cytological analysis was modified from Joseph (1984) and Sharma and Sharma (1980). The root tips were pretreated in $2 \mathrm{~mm}$ 8-hydroxyquinoline at $17{ }^{\circ} \mathrm{C}$ for $3-5 \mathrm{~h}$ and fixed in Carnoy's fluid $(60 \%$ (v/v) ethanol, 30\% (v/v) chloroform, $10 \%(\mathrm{v} / \mathrm{v})$ acetic acid) at $10{ }^{\circ} \mathrm{C}$ for $10 \mathrm{~min}$ and stored in $70 \%(\mathrm{v} / \mathrm{v})$ ethanol in a refrigerator $\left(12{ }^{\circ} \mathrm{C}\right)$. Root tips were hydrolyzed in $1 \mathrm{~N} \mathrm{HCl}$ at $60{ }^{\circ} \mathrm{C}$ for $15 \mathrm{~min}$ and soaked in $45 \%(\mathrm{v} / \mathrm{v})$ acetic acid for $10 \mathrm{~min}$. The root tips were cut and squashed. Aceto-orcein dye (1-2 droplets) was added onto the root tissues, and the stained tissues were examined at $100 \times$ magnification under a light microscope. Chromosome numbers were counted from at least 10 cells/slide, and the means were calculated.

\section{Results and Discussion}

Mortality and LD response curve. The concentrations of mutagens affect both tissue survival and mutagenic ability. Higher concentrations of mutagens can induce higher mutation rates, but result in lower survivability. By contrast, using lower concentrations of mutagens allow higher survival rates, but result in lower mutation inducibility. Thus, using optimal concentrations of mutagens is necessary for successful mutagenization by balancing the number of plants that survive in reasonable quantities and finding the desired mutations. Normally, LDs that lead to $50 \%$ and $30 \%$ mortality $\left(\mathrm{LD}_{50}\right.$ and $\left.\mathrm{LD}_{30}\right)$ are used and need to be determined for each plant and tissue.

After the PLBs of Dendrobium 'Earsakul' were treated with various $\mathrm{NaN}_{3}$ concentrations and ROW, and transferred to VW1 medium, the mortality of PLBs was highly significantly different between treatments at $3 \mathrm{~d}, 1$ and 2 weeks after the treatments. Higher concentrations reduced the survival rates of the PLBs. For all durations, increasing the concentrations of $\mathrm{NaN}_{3}$ resulted in continuously reduced survival rates of the PLBs. The highest mortality rate was observed when using 2.0 to $4.0 \mathrm{~mm} \mathrm{NaN}_{3}$. After $3 \mathrm{~d}$, the highest percentage of mortality $(100 \%)$ of PLBs was found to be $4.0 \mathrm{~mm}$, followed by $3.0 \mathrm{~mm}(99.57 \%)$ and $2.0 \mathrm{~mm}$ $(90.80 \%)$, respectively. For the first week, $100 \%$ PLB mortality was found at 3.0 and $4.0 \mathrm{~mm}$, followed by $2.0 \mathrm{~mm}(96.52 \%)$. For the second week, $100 \%$ PLB mortality was observed when 2.0,3.0, and $4.0 \mathrm{mM} \mathrm{NaN}_{3}$ were applied, followed by $1.5 \mathrm{~mm} \mathrm{NaN}$ $(96.19 \%)$. However, 0\% mortality was discovered with the ROW (control 1) and $0.0 \mathrm{~mm} \mathrm{NaN}_{3}$ (control 2) after $3 \mathrm{~d}$, and less than $1 \%$ after 1 and 2 weeks. The LD response curve shows the relationships between the mortality of PLBs and the concentrations of $\mathrm{NaN}_{3}$. After two weeks, the PLB mortality did not increase, therefore this duration was used for the determination of $\mathrm{LD}_{30}$ and $\mathrm{LD}_{50}$ from the LD response curve. $\mathrm{LD}_{30}$ and $\mathrm{LD}_{50}$ were determined at 0.1 and $0.5 \mathrm{mM} \mathrm{NaN}_{3}$, respectively, which are optimal concentrations for the future mutagenesis of Dendrobium PLBs (Fig. 1). Under these conditions, the surviving PLBs were green, vigorous and they developed into plantlets.

$\mathrm{NaN}_{3}$ has been used successfully in many plants. The effects and permeation of $\mathrm{NaN}_{3}$ depend on the plant genotypes, nature of tissues (types, sizes, and developmental stages), and/or the mutagen property ( $\mathrm{pH}$ and concentrations). In wheat (Triticum aestivum L. em. Thell.), seeds treated with $9.24 \mathrm{~mm} \mathrm{NaN}_{3}\left(\mathrm{LD}_{50}\right)$ were optimal for induced changes in root and shoot length (Srivastava et al., 2011). Türkan et al. (2006) found that $1 \mathrm{~mm} \mathrm{NaN}_{3}\left(\mathrm{LD}_{50}\right)$ treatment of seeds was optimal for induced mutation in pea. Meanwhile, $4.62 \mathrm{~mm} \mathrm{NaN}_{3}\left(\mathrm{LD}_{50}\right)$ was an optimal concentration for induced mutation in groundnut (A. hypogaea L.) seeds (Mensah and Obadoni, 2007). In addition, $50 \mathrm{~mm} \mathrm{NaN}_{3}$ $\left(\mathrm{LD}_{50}\right)$ was an optimal concentration for inducing increase in the amount of proteins and fats in seeds of 'Samnut 20' peanut (Animasaun et al., 2014). When carnation (Diathus caryophyllus L.) seeds were treated with $107.66 \mathrm{~mm} \mathrm{NaN}\left(\mathrm{LD}_{50}\right)$, changes were observed in pollen sterility and agro-metrical traits (Roychowdhury and Tah, 2011). In

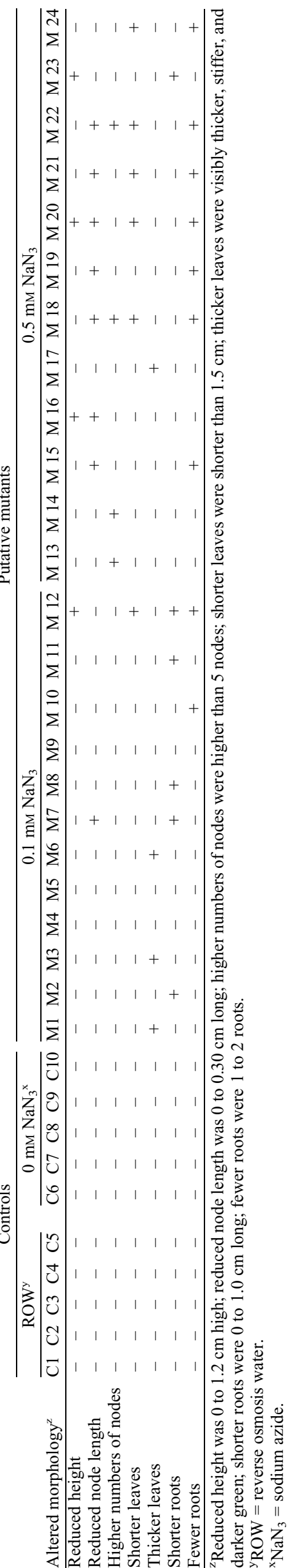


tufted airplant (Guzmania) and silver vase (Aechmea bromeliad), the survival rates of shoots treated with $0.5 \mathrm{~mm} \mathrm{NaN}_{3}$ for $60 \mathrm{~min}$ were $51.30 \%\left(\mathrm{LD}_{50}\right)$, and all explants treated with $2.0 \mathrm{~mm} \mathrm{NaN}_{3}$ showed browning and/or were dead (Huang, 2012). In this report, we successfully induced mutation of Dendrobium 'Earsakul' using $\mathrm{NaN}_{3}$. The $\mathrm{LD}_{50}(0.5 \mathrm{~mm})$ from our study was similar to the $\mathrm{LD}_{50}(0.5 \mathrm{~mm})$ of tufted airplant and silver vase shoots. However, $\mathrm{LD}_{50}$ of carnation seeds were much higher (107.66 mM). Similarly, $\mathrm{LD}_{50}$ of seeds of field crops (pea, groundnut, wheat, and peanut) were higher (1, 4.62, 9.24, $50 \mathrm{~mm}$, respectively), substantiating the genotypic and tissue-specific dependency of $\mathrm{NaN}_{3}$ treatments.

Morphological analysis. The 6-month-old plantlets were transferred to a greenhouse for further evaluation of desirable traits and multiplication. Morphological analysis was performed with 24 putative mutants (M1 to M12 from $L_{30}$ and M13 to M24 from $L_{50}$ treatments) and 10 controls ( $\mathrm{C} 1$ to $\mathrm{C} 5$ from control 1 and $\mathrm{C} 6$ to $\mathrm{C} 10$ from control 2). The average plant height and numbers of leaves were not significantly different between $\mathrm{NaN}_{3}$ concentrations. The lack of difference in height probably results from the significantly higher average numbers of nodes, but lower average node length in putative mutants $(0.1$ and $0.5 \mathrm{mM} \mathrm{NaN}_{3}$ ) compared with controls. Putative mutants treated with $0.5 \mathrm{mM} \mathrm{NaN}_{3}$ had the highest average numbers of nodes ( 4.75 nodes), which was 1.8-fold higher than those of controls. By contrast, average node length, leaf width, root length, and numbers of roots were significantly lower $(P \leq 0.05)$ in putative mutants compared with controls. In addition, the average leaf length of putative mutants from $0.5 \mathrm{~mm} \mathrm{NaN}_{3}$ treatment was significantly lower than that of ROW (control 1), however, it was not significantly different when compared with those of $0 \mathrm{~mm} \mathrm{NaN} \mathrm{N}_{3}$ (control 2) and putative mutants from $0.1 \mathrm{~mm} \mathrm{NaN} \mathrm{N}_{3}$ treatment (Table 1). All plants from different $\mathrm{NaN}_{3}$ concentrations had similar leaf arrangement as controls and they did not form any new shoots. However, some putative mutants (M1, M3, M6, and M17) had thicker leaves compared with others (Table 2). These morphological alterations may result from either genetic changes as a result of mutation or physiological changes from $\mathrm{NaN}_{3}$ treatments. The morphological alterations of these mutants will also be evaluated at the flowering stage in the future.

All plants treated with ROW and $0 \mathrm{~mm}$ $\mathrm{NaN}_{3}$ (controls) were without any morphological alterations $(0 \%)$. By contrast, most plants treated with 0.1 and $0.5 \mathrm{~mm} \mathrm{NaN}_{3}$ had altered morphological characteristics $(75 \%$ and $100 \%$, respectively). In general, using higher $\mathrm{NaN}_{3}$ concentration had a tendency to result in multiple morphological alterations. When treated with $0.1 \mathrm{~mm} \mathrm{NaN}_{3}$, the majority of putative mutants (seven) had changes in only one characteristic while one, zero, and one putative mutants had two, three, and four characteristic changes, respectively. By contrast, when using higher concentration of $0.5 \mathrm{~mm} \mathrm{NaN}_{3}$, only three putative mutants had changes in one characteristic while five, one, and three putative mutants had two, three and four characteristic changes, respectively (Table 2). Reduced height, reduced node length, shorter leaves, and fewer roots were observed in putative mutants from $0.5 \mathrm{~mm} \mathrm{NaN}_{3}$ treatment at higher percentages than those from $0.1 \mathrm{~mm} \mathrm{NaN}_{3}$ treatment (3-fold, 7-fold, 5-fold, and 3.5-fold, respectively) and only putative mutants from $0.5 \mathrm{~mm} \mathrm{NaN}_{3}$ treatment were found with higher numbers of nodes $(33.33 \%)$. By contrast, the percentages of putative mutants from the $0.1 \mathrm{~mm} \mathrm{NaN}$ treatment that had thicker leaves and shorter roots were 3-fold and 5-fold greater than those from the $0.5 \mathrm{~mm}$ $\mathrm{NaN}_{3}$ treatment, respectively (Table 3). Whereas the $0.5 \mathrm{~mm} \mathrm{NaN}_{3}$ treatment induced multiple morphological alterations, and it also negatively affected the growth and survival of plants. Therefore, using $0.1 \mathrm{mM} \mathrm{NaN}_{3}$ treatment may be more appropriate.

These results show that $\mathrm{NaN}_{3}$ contributed to an increase in morphological variability, which may be due to a delay of or inhibition

Table 3. The percentages of plants having altered morphology of 24 putative mutants $\left[0.1 \mathrm{~mm} \mathrm{NaN}_{3}(\mathrm{M} 1\right.$ to M12) and $0.5 \mathrm{mM} \mathrm{NaN}_{3}$ (M13 to M24)] and 10 controls [ROW; control 1 (C1 to C5), 0 mM; control 2 (C6 to C10)] of Dendrobium 'Earsakul' at 6 months.

\begin{tabular}{|c|c|c|c|c|}
\hline \multirow[b]{3}{*}{ Altered morphology ${ }^{y}$} & \multicolumn{4}{|c|}{ Plants with altered morphology $(\%)^{z}$} \\
\hline & \multicolumn{2}{|r|}{ Controls } & \multicolumn{2}{|c|}{ Putative mutants } \\
\hline & $\mathrm{ROW}^{\mathrm{x}}$ (control 1) & $0 \mathrm{mM} \mathrm{NaN}_{3}{ }^{\mathrm{w}}$ (control 2) & $0.1 \mathrm{mM} \mathrm{NaN}_{3}$ & $0.5 \mathrm{mM} \mathrm{NaN}_{3}$ \\
\hline Reduced height & 0.00 & 0.00 & 8.33 & 25.00 \\
\hline Reduced node length & 0.00 & 0.00 & 8.33 & 58.33 \\
\hline Higher numbers of nodes & 0.00 & 0.00 & 0.00 & 33.33 \\
\hline Shorter leaves & 0.00 & 0.00 & 8.33 & 41.67 \\
\hline Thicker leaves & 0.00 & 0.00 & 25.00 & 8.33 \\
\hline Shorter roots & 0.00 & 0.00 & 41.67 & 8.33 \\
\hline Fewer roots & 0.00 & 0.00 & 16.67 & 58.33 \\
\hline
\end{tabular}

${ }^{\mathrm{z}}$ Percentages of plants with altered morphology $=$ (No. of plants with altered morphology/total number of plants) $\times 100$.

${ }^{\mathrm{y}}$ Reduced height was 0 to $1.2 \mathrm{~cm}$ high; reduced node length was 0 to $0.30 \mathrm{~cm}$ long; higher numbers of nodes were higher than 5 nodes; shorter leaves were shorter than $1.5 \mathrm{~cm}$; thicker leaves were visibly thicker, stiffer, and darker green; shorter roots were 0 to $1.0 \mathrm{~cm}$ long; fewer roots were 1 to 2 roots.

${ }^{\mathrm{x}} \mathrm{ROW}=$ reverse osmosis water.

${ }^{\mathrm{w}} \mathrm{NaN}_{3}=$ sodium azide.

Table 4. Primer sequences, annealing temperature, numbers of total scorable DNA bands, numbers of polymorphic DNA bands, percentages of polymorphism, and amplified band size for each intersimple sequence repeat (ISSR) primer used for the analysis of 24 putative Dendrobium 'Earsakul' mutants and the controls.

\begin{tabular}{|c|c|c|c|c|c|c|}
\hline Primers & $\begin{array}{c}\text { Primer } \\
\text { sequences }\end{array}$ & $\begin{array}{l}\text { Annealing } \\
\text { temp }\left({ }^{\circ} \mathrm{C}\right)\end{array}$ & $\begin{array}{c}\text { No. of } \\
\text { total } \\
\text { bands }\end{array}$ & $\begin{array}{c}\text { No. of } \\
\text { polymorphic } \\
\text { bands }\end{array}$ & $\begin{array}{l}\text { Polymorphism } \\
(\%)\end{array}$ & $\begin{array}{c}\text { Amplified } \\
\text { band size } \\
\text { (bp) }\end{array}$ \\
\hline$\overline{\text { ISSR } 801}$ & $(\mathrm{AT})_{8} \mathrm{~T}$ & 53 & 19 & 6 & 31.6 & $500-4,800$ \\
\hline ISSR 807 & $(\mathrm{AG})_{8} \mathrm{~T}$ & 53 & 17 & 2 & 11.8 & $350-3,800$ \\
\hline ISSR 811 & $(\mathrm{GA})_{8} \mathrm{C}$ & 53 & 22 & 1 & 4.5 & $240-4,100$ \\
\hline ISSR 812 & $(\mathrm{GA})_{8} \mathrm{~A}$ & 53 & 13 & 0 & 0.0 & $340-4,800$ \\
\hline ISSR 817 & $(\mathrm{CA})_{8} \mathrm{~A}$ & 53 & 13 & 6 & 46.2 & $380-4,400$ \\
\hline ISSR 818 & $(\mathrm{CA})_{8} \mathrm{G}$ & 53 & 29 & 20 & 69.0 & $280-3,000$ \\
\hline ISSR 825 & $(\mathrm{AC})_{8} \mathrm{~T}$ & 53 & 10 & 2 & 20.0 & $300-4,400$ \\
\hline ISSR 827 & $(\mathrm{AC})_{8} \mathrm{G}$ & 53 & 10 & 2 & 20.0 & $320-4,000$ \\
\hline ISSR 829 & $(\mathrm{TG})_{8} \mathrm{C}$ & 58 & 21 & 14 & 66.7 & $400-4,300$ \\
\hline ISSR 834 & $(\mathrm{AG})_{8} \mathrm{YT}^{\mathrm{z}}$ & 58 & $\mathrm{NR}^{\mathrm{y}}$ & NR & $\mathrm{NA}^{\mathrm{x}}$ & NA \\
\hline ISSR 835 & $(\mathrm{AG})_{8} \mathrm{YC}$ & 48 & 17 & 2 & 11.8 & $200-4,400$ \\
\hline ISSR 840 & $(\mathrm{GA})_{8} \mathrm{YT}$ & 48 & 23 & 8 & 34.8 & $220-4,100$ \\
\hline \multicolumn{2}{|c|}{ The 11 clear and reproducible } & Total & 194 & 63 & & \\
\hline \multicolumn{2}{|c|}{ ISSR primers } & Average & 17.6 & 5.7 & 28.7 & \\
\hline \multicolumn{2}{|c|}{ The 10 polymorphic } & Total & 181 & 63 & & \\
\hline \multicolumn{2}{|c|}{ ISSR primers } & Average & 18.1 & 6.3 & 31.6 & \\
\hline
\end{tabular}

${ }^{\mathrm{z}} \mathrm{Y}=$ pyrimidines $(\mathrm{C}, \mathrm{T})$.

${ }^{\mathrm{y}} \mathrm{NR}=$ nonreproducible.

${ }^{\mathrm{x}} \mathrm{NA}=$ not available. 
cotton (Gossypium herbaceum L.), seeds treated with $10 \mathrm{~mm} \mathrm{NaN}_{3}$ for 180 min encouraged changes in root length and number of roots (Ganesan et al., 2005). In wheat seeds treated with $3.08,6.16$, and $9.24 \mathrm{~mm} \mathrm{NaN}_{3}$ reduced the germination percentages, root length, and shoot length, while yield attributing characters showed both positive and negative shift in means compared with control (Srivastava et al., 2011). When bluebells were treated with different $\mathrm{NaN}_{3}$ concentrations, the highest (12.3 mM) $\mathrm{NaN}_{3}$ concentration was found to increase the number of branches and leaves, chlorophyll content, fresh weights of shoots and roots, dry weights of shoots and roots, and root length. In addition, all concentrations (3.7, 6.15, 9.2, and $12.3 \mathrm{~mm}$ ) of $\mathrm{NaN}_{3}$ induced changes in flower color, flower shape, and leaf form (El-Mokadem and Mostafa, 2014).

Identification of mutants with ISSR markers. The genetic variability of 24 putative Dendrobium 'Earsakul' mutants, which were obtained from $0.1 \mathrm{~mm}$ and $0.5 \mathrm{~mm} \mathrm{NaN} \mathrm{N}_{3}$ treatments, and 10 controls were analyzed using 12 ISSR primers. It should be noted that changes in ISSR profiles were not necessarily correlated with changes in vegetative morphological traits. One of the primers, ISSR 834, amplified complex nonreproducible DNA patterns and was withdrawn from further analysis. Of the 11 ISSR primers that produced clear and reproducible amplicon profiles, 10 were polymorphic and 1 was monomorphic (Table 4). All controls except $\mathrm{C} 3$ gave similar DNA profiles with all 10 polymorphic primers. C3 was genetically differentiated by ISSR 817 ; however, it was morphologically identical to other controls (Fig. 2). This single band change may be a result of genetic variation arising from somaclonal variation during in vitro culture. Types of tissues and explants, types and components of culture media, duration and methods of culture are factors that may be involved in inducing somaclonal variation during in vitro culture, possibly via the modification of DNA methylation patterns (Leva et al., 2012).

The 11 clear and reproducible ISSR primers amplified a total of 194 fragments across all genotypes, of which 63 fragments were polymorphic, giving a polymorphism percentage of $32.47 \%$. On average, 17.6 total fragments, varying from 10 to 29 , and 5.7 polymorphic fragments, ranging from 0 to 20 , were amplified per primer. The length of amplified ISSR fragments ranged from 200 bp (ISSR 835) to 4800 bp (ISSR 801). Whereas, the 10 polymorphic ISSR primers amplified a total of 181 fragments across all genotypes of which 63 fragments were polymorphic, resulting in a polymorphism percentage of $34.81 \%$. On average, 18.1 total fragments and 6.3 polymorphic fragments were obtained per primer. The ISSR 818 gave the highest percentage of polymorphism $(69.0 \%)$, followed by ISSR $829(66.7 \%)$ and ISSR $817(46.2 \%)$ (Table 4). This set of ISSR primers have been used to evaluate 28 Dendrobium 'Earsakul' putative mutants from 0.25 to $5 \mathrm{mM} \mathrm{NaN}_{3}$ treatments in our previous work. It was found that the polymorphism percentage was higher in this work $(34.81 \%)$ than that in our previous work (22.54\%), suggesting that the polymorphism percentage may vary according to plant population used and indicating the importance of using optimal $\mathrm{NaN}_{3}$ concentrations for inducing mutation. In both works, ISSR 818 gave high percentages of polymorphism $(69.0 \%$ in this work and $42.9 \%$ in previous work), indicating its usefulness in this orchid species (Wannajindaporn et al., 2014).

Using the 10 polymorphic ISSR primers, 20 $(83.33 \%)$ of 24 putative mutants induced by 0.1 and $0.5 \mathrm{~mm} \mathrm{NaN}_{3}$ showed altered amplified DNA profiles compared with the majority of controls and were identified as mutants. Unique bands ( 38 bands) were found in 13 mutants: one band in M2, M15, M16, and M18, two bands in M7, M10, M11, M12, and
M21, three bands in M17, four bands in M19, five bands in M20, and six bands in M9. These genotype-specific bands were amplified from eight primers (ISSR 801, 807, 811, 817, 818, 825,829 , and 840 ) and are very valuable for DNA fingerprinting and identifying these mutants. These results indicate that $\mathrm{NaN}_{3}$ is highly effective in causing mutations and would be particularly useful for Dendrobium breeding in the future and the 10 polymorphic ISSR markers were effective for identifying the genetic variation as a result of induced mutation and somaclonal variation. Similarly, ISSR markers were also effective for genetic analysis in other orchids such as foxtail orchid (Parab and Krishnan, 2008), spring orchid (Wang et al., 2009b; Yao et al., 2007), and jewel orchid (Zhang et al., 2010).
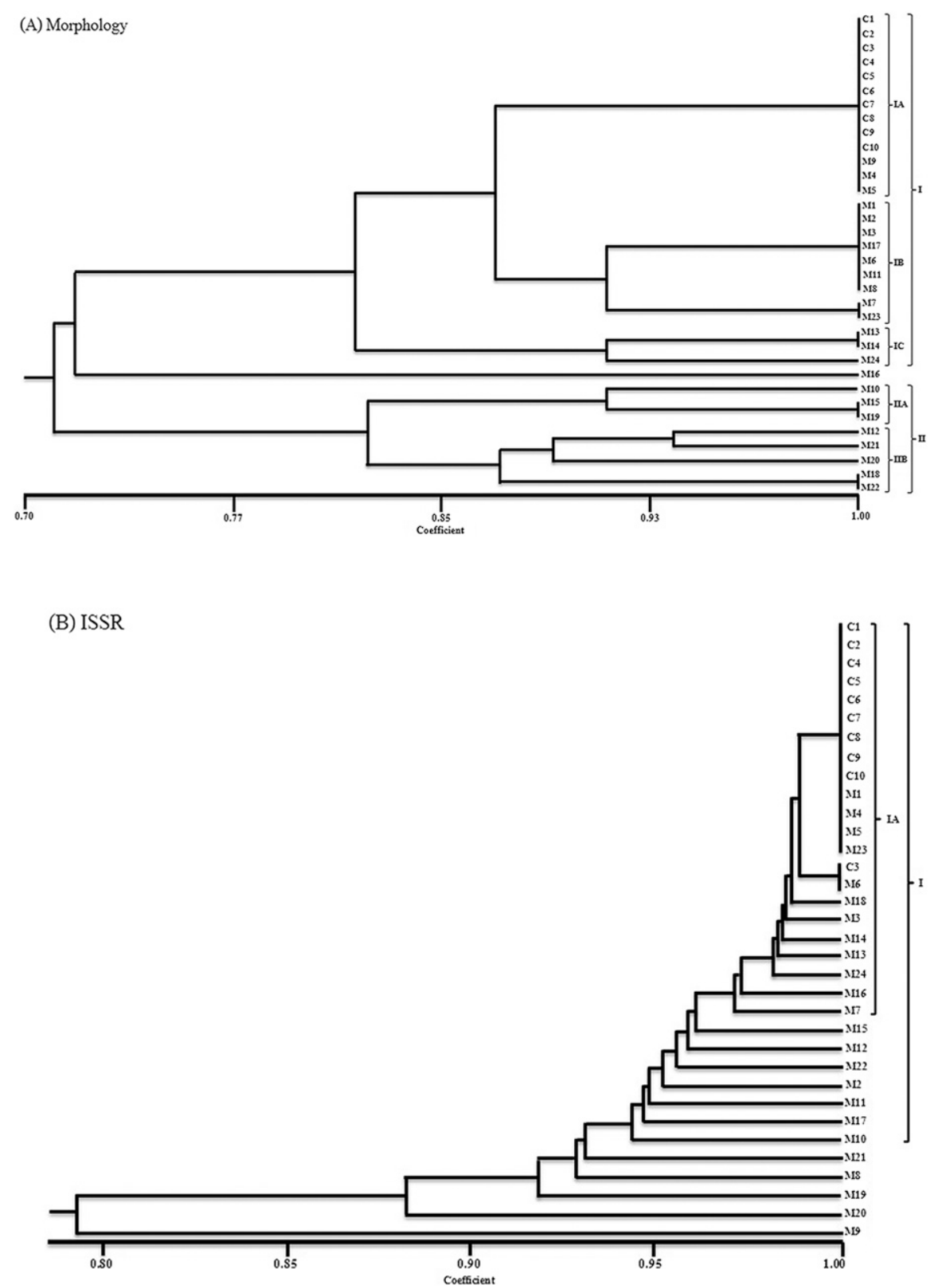

Fig. 2. (A) Morphological characteristics, (B) intersimple sequence repeat (ISSR) derived dendrogram of 24 putative mutants [0.1 $\mathrm{mm} \mathrm{NaN}_{3}$ (M1 to M12) and $0.5 \mathrm{~mm} \mathrm{NaN}_{3}$ (M13 to M24)] and 10 controls (ROW; control 1 (C1 to C5), 0 mM; control 2 (C6 to C10)] of Dendrobium 'Earsakul' at 6 months generated by unweighted pair group method with arithmetic average. 
The absence of ISSR fragments or the presence of additional ISSR fragments may result either from the loss/gain of primer binding sites as a result of changes in the nucleotide sequences (e.g., point mutations) or changes that alter the size or prevent the successful amplification of a target DNA (e.g., deletions, duplications, inversions, or translocations) (Wannajindaporn et al., 2014). The mechanism of $\mathrm{NaN}_{3}$ is mediated through the production of organic metabolites of the azide compound in plant cells. The enzyme O-acetylserine sulfhydrylase catalyzes the condensation of azide $\left(\mathrm{N}_{3}{ }^{-}\right)$or sulfide $\left(\mathrm{S}^{2-}\right)$ with $\mathrm{O}$-acetylserine to produce $\mathrm{L}$-azidoalanine $\left(\mathrm{N}_{3}-\mathrm{CH}_{2}-\mathrm{CH}\left(\mathrm{NH}_{2}\right)-\mathrm{COOH}\right)$ or L-cysteine. This L-azidoalanine metabolite is chemically identified in plant cells as an amino acid analogue that may cause point mutations during DNA replication (Kredich, 1971; LaVelle and Mangold, 1987; Owais and Kleinhofs, 1988). $\mathrm{NaN}_{3}$ can cause disorders on DNA, particularly the bp substitution (transversion; $\mathrm{A} / \mathrm{G} \rightleftharpoons \mathrm{T} / \mathrm{C}$ ), which can lead to amino acid changes, resulting in a change in the function of proteins (Al-Qurainy and Khan, 2009).

Comparison between morphological and ISSR analysis. Seven morphological characteristics were used to construct a dendrogram based on cluster analysis using UPGMA. The Mantel test with a cophenetic correlation coefficient value of $0.84(P \leq 0.01)$ indicated that data in the similarity matrix were well represented by the dendrogram. The dendrogram grouped the 24 putative mutants and 10 controls into two clusters and one individual (M16) at the genetic similarity level of 0.80 (Fig. 2A). Fifteen putative mutants were grouped in cluster I along with all controls. This cluster was divided into three subclusters (IA, IB, and IC). Subcluster IA consisted of three putative mutants (M4, M5, and M9), which were morphologically identical to controls and all 10 controls. Subcluster IB consisted of seven putative mutants (M1, M2, M3, M6, M8, M11, and M17) and two morphologically related putative mutants (M7 and M23). Subcluster IC consisted of two putative mutants (M13 and M14), which were morphologically identical and M24. By contrast, Cluster II was divided into two subclusters (IIA and IIB). Subcluster IIA consisted of two putative mutants (M15 and M19), which were morphologically identical and M10. The remaining putative mutants, M12, M20, M21, and the two morphologically identical M18 and M22, were grouped into cluster IIB. Interestingly, one and four putative mutants in cluster IIB that resulted from 0.1 and $0.5 \mathrm{~mm} \mathrm{NaN}_{3}$ treatments had three to four altered morphological characteristics. In clusters I and II, putative mutants from 0.1 and $0.5 \mathrm{~mm} \mathrm{NaN}_{3}$ treatments clustered together in the same subclusters. Three-dimensional plots of PCoA based on morphological characters were generally consistent with the UPGMA cluster analysis; the three coordinates accounted for $48.79 \%$, $24.28 \%$, and $12.46 \%$ with a total of $88.40 \%$ of the total variance. The PCoA can differentiate controls and putative mutants into two large groups as well as the UPGMA cluster analysis. However, the separation of M12, M18, M20, M21, and M22 from the rest was more clearly observed (Fig. 3A). Jaccard's genetic similarity coefficients among the pairwise combinations of genotypes ranged from 0.545 to 1.000 . The putative mutants M18, $\mathrm{M} 20$, and M22 were found to be the most morphologically dissimilar from the controls (genetic similarity coefficient $=0.600)$, followed by M12 (0.667) and M21 (0.727).

The ISSR polymorphic bands were used to construct a dendrogram based on cluster analysis using UPGMA. The grouping of putative mutants and the controls in the

dendrogram indicates the genetic distinctness of the genotypes studied as they were placed in different clusters/groups. The Mantel test with a cophenetic correlation coefficient value of $0.97(P \leq 0.01)$ indicates that data in the similarity matrix are well represented by the dendrogram. The dendrogram grouped the 24 putative mutants and 10 controls into one large cluster and five separate individuals at the genetic similarity level of 0.94 (Fig. 2B). Four putative mutants (M1, M4, M5, and M23) were genetically identical to the majority of controls. Only C3 was genetically differentiated from other controls and may represents
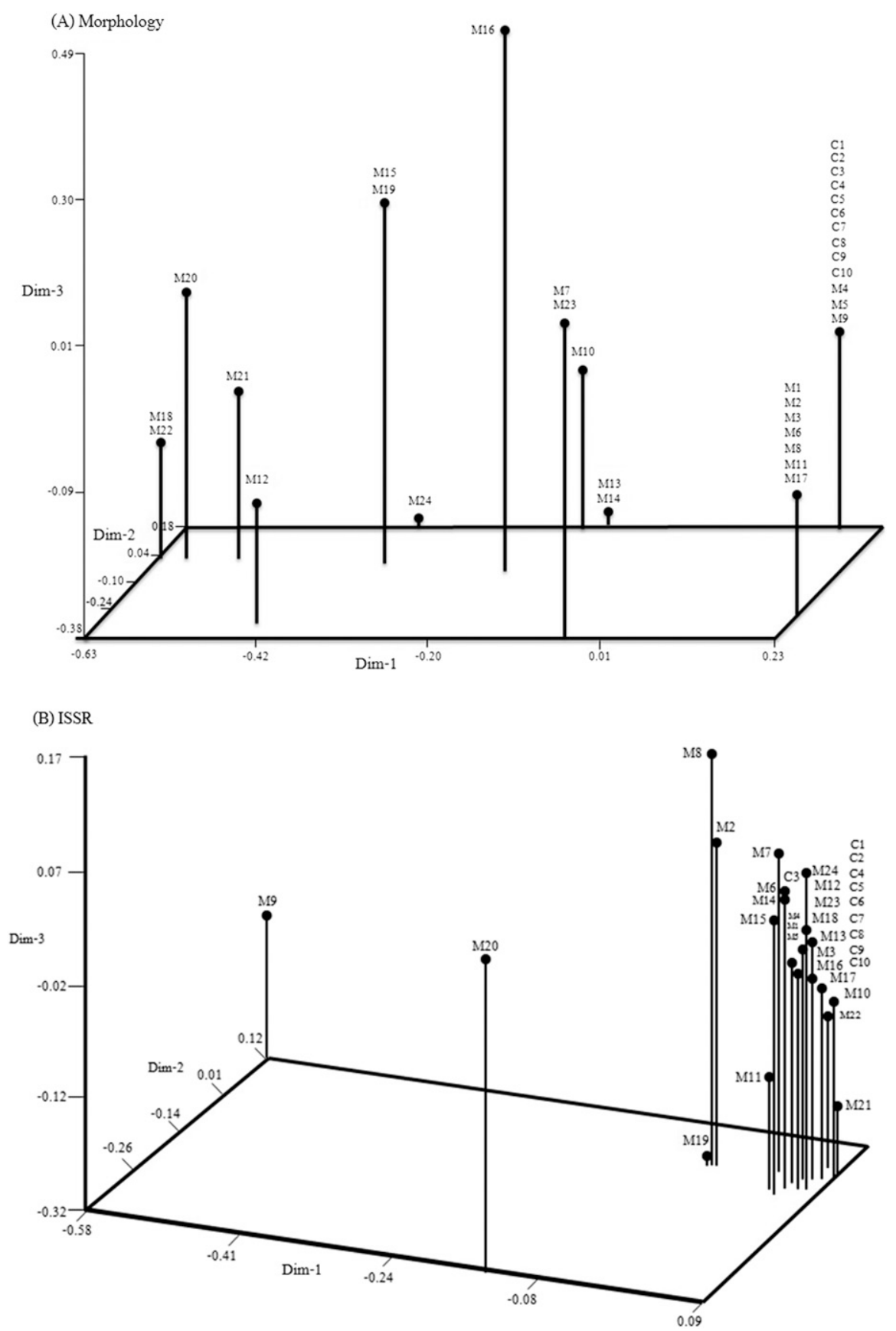

Fig. 3. (A) Morphological characteristics, (B) intersimple sequence repeat (ISSR) derived threedimensional plot based on the first three principal coordinates from a principal coordinate analysis of 24 putative mutants [0.1 $\mathrm{mm} \mathrm{NaN}_{3}$ (M1 to M12) and $0.5 \mathrm{~mm} \mathrm{NaN}_{3}$ (M13 to M24)] and 10 controls [ROW; control 1 (C1 to C5), 0 mM; control 2 (C6 to C10)] of Dendrobium 'Earsakul' at 6 months. 
a somaclonal variant. Cluster I was divided into one subcluster (IA) and seven separate individuals (M2, M10 to M12, M15, M17, and M22). Subcluster IA consisted of 10 controls and 12 putative mutants (M1, M3 to M7, M13, M14, M16, M18, M23, and M24). While the remaining mutants, M8, M9, M19, M20, and M21, could not be grouped into any of the clusters (Fig. 2B). In total, nine (75.00\%) of 12 putative mutants (M2, M3, M6 to M12) induced by $0.1 \mathrm{~mm} \mathrm{NaN}_{3}$ treatment and 11 $(91.67 \%)$ of 12 putative mutants (M13 to M22, M24) induced by $0.5 \mathrm{~mm} \mathrm{NaN}_{3}$ treatment were genetically differentiated from controls and were identified as mutants.

Three-dimensional plots of PCoA based on ISSR markers were generally consistent with the UPGMA cluster analysis; the three coordinates accounted for $24.39 \%, 11.25 \%$, and $9.54 \%$ with a total of $45.18 \%$ of the total variance. The PCoA differentiated controls and putative mutants into one large group as well as the UPGMA cluster analysis. However, the separation of M9 and M20 from the rest was more clearly observed (Fig. 3B). Jaccard's genetic similarity coefficients among the pairwise combinations of genotypes ranged from 0.729 (M9 and M21) to 1.000. The mutant M9 was found to be the most genetically dissimilar from the control (genetic similarity coefficient $=0.795)$, followed by M20 (0.897), M19 (0.930), M8 (0.940), and M21 (0.983), respectively. Four putative mutants (M1, M4, M5, and M23) displayed identical genetic profiles with controls at all 194 loci evaluated and may represent genetically unaltered plants. However, it is also possible that these loci may not cover the genetic changes in these plants. Six pairs of mutants (M1 and M4, M1 and M5, M1 and M23, M4 and M5, M4 and M23, and M5 and M23) had similar coefficients (1.000) with each other within a pair, but they were distinct from the controls.

When the morphological and ISSR analysis were compared with the 24 putative Dendrobium 'Earsakul' mutants and 10 controls, M4 and M5 were found not to have changes when compared with controls in either the analysis. However, M1 and M23 with slightly altered morphology were found not to have any changes in their DNA patterns, suggesting that these morphological changes may result from the physiological effects of $\mathrm{NaN}_{3}$ or the environmental effects. It is also possible that the genetic changes in these mutants were not detectable by these 194 ISSR loci. By contrast, C3 and M9 had no morphological alterations, but differed genetically according to the ISSR analysis, suggesting that the changes in DNA may occur in positions that are not genes or in genes that are not expressed at this developmental stage and in this environment. The correlation between similarity matrices of morphological and ISSR markers was $0.12(P>0.05)$, indicating the unrelatedness of the two markers for genetic differentiation. The correlation between the matrices of cophenetic correlation was also unrelated $(r=0.19 ; P>0.05)$. It should be noted that M9, which was the most genetically distinct from controls, had the same morphological characters as controls, substantiating the unrelatedness of the two markers. The flower characteristics of this mutant will be evaluated in the future to determine whether it is useful commercially. These results may have arisen because the diversity at the molecular level, which is neutral, may not reflect diversity at the morphological level (Karhu et al., 1996; Tar'an et al., 2005). Moreover, the morphological data were based on only seven major characteristics, which may be too few to reflect the actual variability among the genotypes (Tantasawat et al., 2010a). Meanwhile, the unrelatedness of correlation between morphological and DNA markers was also observed in cowpea (Nkongolo, 2003) and yard long bean (Tantasawat et al., 2010a). It appears that ISSR markers had higher mutant differentiation capability than morphological characters because they were able to differentiate 19 of $24(79.2 \%)$ putative mutants while only eight of $24(33.3 \%)$ putative mutants were morphologically distinct, indicating their higher efficiency.

Cytological analysis. $\mathrm{NaN}_{3}$ can induce changes in chromosome numbers and/or cause damage to chromosomes (Klášterská et al., 1976). In barley, it reduced the frequency of chromatid movement in the metaphase stage which affected the chromosome numbers (Pearson et al., 1975, Velemínský et al., 1977). However, in our experiment, all plants that were treated with ROW and $0 \mathrm{~mm} \mathrm{NaN}_{3}$ (controls) and 0.1 and $0.5 \mathrm{~mm} \mathrm{NaN}_{3}$ were diploid $(2 n=2 x=24) . \mathrm{NaN}_{3}$ at both concentrations did not affect the chromosome numbers of Dendrobium 'Earsakul'. Nevertheless, to determine the relationships more accurately, a larger population of mutants is required.

\section{Conclusion}

Our results indicate the effectiveness of $\mathrm{NaN}_{3}$ as a chemical mutagen for in vitro mutagenesis of Dendrobium 'Earsakul'. Moreover, ISSR markers were effective for the identification of the resulting mutants. Induction of genetic variation by in vitro mutagenesis and selection of mutants by ISSR analysis are powerful tools for the future improvement of Dendrobium. Twenty mutants were identified from this experiment and at present, they are being cultivated for future evaluation of their ornamental characters.

\section{Literature Cited}

Adebola, M.O. 2013. Mutagenic effects of sodium azide $\left(\mathrm{NaN}_{3}\right)$ on morphological characteristics of tomato (Lycopersicum esculentum). Res. J. Sci. IT Mgt. 2:1-5.

Al-Qurainy, F. 2009. Effects of sodium azide on growth and yield traits of Eruca sativa (L.). World Appl. Sci. J. 7:220-226.

Al-Qurainy, F. and S. Khan. 2009. Mutagenic effects of sodium azide and its application in crop improvement. World Appl. Sci. J. 6:1589-1601.

Animasaun, D.A., S. Oyedeji, M.A. Azeez, and A.O. Onasanya. 2014. Alkylating efficiency of sodium azide on pod yield, nut size and nutrition composition of Samnut 10 and Samnut 20 varieties of groundnut (Arachis hypogea L.). Afr. J. Food Agr. Nutr. Dev. 14:9497-9510.

Ansari, S.A., C. Narayanan, S.A. Wali, R. Kumar, N. Shukla, and S.K. Rahanǵdale. 2012. ISSR markers for analysis of molecular diversity and genetic structure of Indian teak (Tectona grandis L.f.) populations. Ann. For. Res. 55:11-23.

Atichart, P. 2013. Polyploid induction by colchicine treatments and plant regeneration of Dendrobium chrysotoxum. Thai J. Agr. Sci. 46:59-63.

Baloch, F.S., C. Kurt, H. Arioğlu, and H. Özkan. 2010. Assaying of diversity among soybean (Glycine max (L.) Merr.) and peanut (Arachis hypogaea L.) genotypes at DNA level. Turk. J. Agr. 34:285-301.

Barakat, M.N., R.S. Abdel Fattah, M. Badr, and M.G El-Torky. 2010. In vitro mutagenesis and identification of new variants via RAPD markers for improving Chrysanthemum morifolium. Afr. J. Agr. Res. 5:748-757.

Bidabadi, S.S., S. Meon, Z. Wahab, S. Subramaniam, and M. Mahmood. 2012. Induced mutations for enhancing variability of banana (Musa spp.) shoot tip cultures using ethyl methanesulphonate (EMS). Austral. J. Crop Sci. 6:391-401.

Brown-Guedira, G.L., J.A. Thompson, R.L. Nelson, and M.L. Warburton. 2000. Evaluation of genetic diversity of soybean introductions and North American ancestors using RAPD and SSR markers. Crop Sci. 40:815-823.

Dahot, M.U., E. Rind, and M. Rafiq. 2011. Physical and biochemical analysis of sodium azide treated Sorghum bicolor (L.). Monech. Pak. J. Biotechnol. 8:67-72.

El-Mokadem, H.E. and G.G. Mostafa. 2014. Induction of mutations in Browallia speciosa using sodium azide and identification of the genetic variation by peroxidase isozyme. Afr. J. Biotechnol. 13:106-111.

Ganesan, M., P. Bhanumathi, and N. Jayabalan. 2005. Mutagenic effect of sodium azide on somatic embryo regeneration and root growth of cotton (Gossypium hirsutum L. CV. SVPR2). J. Agr. Sci. Technol. 1:365-380.

Huang, P.L. 2012. Preliminary studies on mutagenic effect of sodum azide and $\gamma$-ray irradiation on organogenesis in Guzmania and Aechmea bromeliads. Res. Bul. Koohsiung District Agr. Res. Ext. Sta. 21:28-38.

Jeng, T.L., Y.J. Shih, C.C. Lai, M.T. Wu, and J.M. Sung. 2010. Anti-oxidative characterization of $\mathrm{NaN}_{3}$-induced common bean mutants. Food Chem. 119:1006-1011.

Jeng, T.L., T.H. Tseng, C.S. Wang, C.L. Chen, and J.M. Sung. 2006. Yield and grain uniformity in contrasting rice genotypes suitable for different growth environments. Field Crops Res. 99:59-66.

Joseph, A. 1984. Orchid biology: Review and perspectives. Cornell University, Ithaca, NY. 410 p.

Karhu, A., P. Hurme, K. Karjalainen, P. Karvonen, K. Kärkkäinen, D. Neale, and O. Savolainen. 1996. Do molecular markers reflect patterns of differentiation in adaptive traits of conifers? Theor. Appl. Genet. 93:215-221.

Keim, P., W. Beavis, J. Schupp, and R. Freestone. 1992. Evaluation of soybean RFLP marker diversity in adapted germ plasm. Theor. Appl. Genet. 85:205-212.

Khan, S., F. Al-Qurainy, and F. Anwar. 2009. Sodium azide: A chemical mutagen for enhancement of agronomic traits of crop plants. Environ. We Intl. J. Sci. Technol. 4:1-21.

Khan, S., M.R. Wani, and K. Parveen. 2004. Induced genetic variability for quantitative traits in Vigna radiata (L.). Wilczek. Pak. J. Bot. 36:845-850

Khatri, A., S. Bibi, M.U. Dahot, I.A. Khan, and G.S. Nizamani. 2011. In vitro mutagenesis in banana 
and variant screening through ISSR. Pak. J. Bot. 43:2427-2431.

Khawale, R.N., S.K. Singh, and Y. Vimala. 2006. Gamma rays induced in vitro mutagenesis and molecular marker-assisted selection of mutants in grapevine. Acta Hort. (725):643-651.

Khosravi, A.R., M.A. Kadir, S.B. Kadzemin, F.Q. Zaman, and A.E. De Silva. 2009. RAPD analysis of colchicine induced variation of the Dendrobium Serdang Beauty. Afr. J. Biotechnol. 8:1455-1465.

Klášterská, I., A.T. Natarajan, and C. Ramel. 1976. An interpretation of the origin of subchromatid aberrations and chromosome stickiness as a category of chromatid aberrations. Hereditas 83:153-162.

Kleinhofs, A., W.M. Owais, and R.A. Nilan. 1978. Azide. Mutat. Res. 55:165-195.

Kredich, N.M. 1971. Regulation of L-cysteine biosynthesis in Salmonella typhimurium. J. Biol. Chem. 246:3474-3484.

Kuchma, O., B. Vornam, and R. Finkeldey. 2011. Mutation rates in Scots pine (Pinus sylvestris L.) from the Chernobyl exclusion zone evaluated with amplified fragment-length polymorphisms (AFLPs) and microsatellite markers. Mutat. Res. 725:29-35.

Kumar, H., M.K. Anubha, Vishwakarma, and J.P. Lal. 2011. Morphological and molecular characterization of Brassica rapa ssp yellow sarson mutants. J. Oilseed Brass. 2:1-6.

Lapointe, F.J. and P. Legendre. 1992. Statistical significance of the matrix correlation coefficient for comparing independent phylogenetic trees. Syst. Biol. 41:378-384.

LaVelle, J.M. and J.B. Mangold. 1987. Structureactivity relationships of the azide metabolite, azidoalanine, in S. typhimurium. Mutat. Res. 177:27-33.

Leva, A.R., R. Petruccelli, and L.M.R. Rinaldi. 2012. Somaclonal variation in tissue culture: A case study with olive. 27 Feb. 2016. $<$ http://dx. doi.org/10.5772/50367>.

Levesque, R. SPSS Inc. 2006. SPSS programming and data management. $3 \mathrm{rd}$ ed. SPSS Institute, Somers, NY.

Luan, V.Q., N.Q. Thien, D.V. Khiem, and D.T. Nhut. 2006. Vitro Germination Capacity and Plant Recovery of Some Native and Rare Orchids. Proc. Intl. Wkshp. Biotechnol. Agr., Ho Chi Minh City, Vietnam, 20-21 Oct. 2006. p. 175-177.

Mantel, N. 1967. The detection of disease clustering and a generalized regression approach. Cancer Res. 27:209-220.

Meesawat, U., T. Srisawat, L. Eksomtramage, and K. Kanchanapoom. 2008. Nuclear DNA content of the pigeon orchid (Dendrobium crumenatum Sw.) with the analysis of flow cytometry. Songklanakarin J. Sci. Technol. 30:277-280.

Mensah, J.K. and B. Obadoni. 2007. Effects of sodium azide on yield parameters of groundnut (Arachis hypogaea L.). Afr. J. Biotechnol. 6:668-671.

Mostafa, G.G. and A.M. Alfrmawy. 2011. RAPD analysis for detection and fingerprinting of sunflower mutants induced by sodium azide. Intl. J. Plant Breed. Genet. 5:277-285.

Mshembula, B.P., J.K. Mensah, and B. Ikhajiagbe. 2012. Comparative assessment of the mutagenic effects of sodium azide on some selected growth and yield parameters of five accessions of cowpeaTvu-3615, Tvu-2521, Tvu-3541, Tvu-3485 and Tvu-3574. Arch. Appl. Sci. Res. 4:1682-1691.

Nkongolo, K.K. 2003. Genetic characterization of Malawian cowpea (Vigna unguiculata (L.) Walp) landraces: Diversity and gene flow among accessions. Euphytica 129:219-228.

Novak, F.J. and H. Brunner. 1992. Plant breeding: Induced mutation technology for crop improvement. IAEA Bull. 4:25-33.
Olsen, O., X. Wang, and D.V. Wettstein. 1993. Sodium azide mutagenesis: Preferential generation of A.T $\rightarrow$ G.C transitions in the barley ant 18 gene. Proc. Natl. Acad. Sci. USA 90:8043-8047.

Owais, W.M. and A. Kleinhofs. 1988. Metabolic activation of the mutagen azide in biological systems. Mutat. Res. 197:313-323.

Palai, S.K. and G.R. Rout. 2011. Characterization of new variety of Chrysanthemum by using ISSR markers. Hortic. Bras. 29:613-617.

Parab, G.V. and S. Krishnan. 2008. Assessment of genetic variation among populations of Rhynchostylis retusa, an epiphytic orchid from Goa, India using ISSR and RAPD markers. Indian J. Biotechnol. 7:313-319.

Pearson, O.W., C. Sander, and R.A. Nilan. 1975. The effect of sodium azide on cell processes in the embryonic barley shoot. Radiat. Bot. 15:315-322.

Petchang, R. 2010. The effect of colchicine concentration and treatment duration on growth and chromosome number in Dendrobium draconis Rchb.f. J. Sci. Technol. Mahasarakham Univ. 29:413-419.

Qari, S.H. 2008. In vitro evaluation of the antimutagenic effect of Origanum majorana extract on the meristemetic root cells of Vicia faba. J. Taibah Univ. Sci. 1:6-11.

Reddy, M.P., N. Sarla, and E.A. Siddiq. 2002. Inter simple sequence repeat (ISSR) polymorphism and its application in plant breeding. Euphytica 128:9-17.

Rohlf, F.J. 2000. Ntsys-pe numerical taxonomy and multivariate analysis system. Version 2.2 user guide. Applied Biostatistics, Inc., Setauket, NY.

Roy, S. and A.K. Biswas. 2005. Isolation of a white flowered mutant through seed culture in Spathoglottis plicata Blume. Cytologia (Tokyo) 70:1-6.

Roychowdhury, R. and J. Tah. 2011. Chemical mutagenic action on seed germination and related agro-metrical traits in M1 Dianthus generation. Curr. Bot. 2:19-23.

Sambrook, J. and D.W. Russell. 2001. Molecular cloning: A laboratory manual. 3rd ed. Cold Spring Harbor Laboratory Press, Cold Spring Harbor, NY. A9.5-A9.7.

Santos, M.D., G.C. Buso, and A.C. Torres. 2008 Evaluation of genetic variability in micropropagated propagules of ornamental pineapple (Ananas comosus var. bracteatus (Lindley) Coppens and Leal) using RAPD markers. Genet. Mol. Res. 7:1097-1105.

Sharma, A.K. and A. Sharma. 1980. Chromosome techniques: Theory and practice. 3 rd ed. Butterworth's, London, UK. p. 9-27.

Shaw, R.K., L. Acharya, and A.K. Mukherjee. 2009. Assessment of genetic diversity in a highly valuable medicinal plant Catharanthus roseus using molecular markers. Crop Breed. Appl. Biotechnol. 9:52-59.

Shi, A., S. Kantartzi, M. Mmbaga, and P. Chen. 2010. Development of ISSR PCR markers for diversity study in dogwood (Cornus spp.). Agr. Biol. J. N. Amer. 1:189-194.

Sideris, E.G., R.A. Nilan, and T.P. Bogyo. 2004. Differential effects of sodium azide on the frequency of radiation-induced chlorophyll mutations in Hordeum vulgare. Radiat. Bot. 13:315-322.

Škorić, D., S. Jocić, Z. Sakač, and N. Lečić. 2008. Genetic possibilities for altering sunflower oil quality to obtain novel oils. Can. J. Physiol. Pharmacol. 86:215-221.

Srivastava, P., S. Marker, P. Pandey, and D.K. Tiwari. 2011. Mutagenic effects of sodium azide on the growth and yield characteristics in wheat (Triticum aestivum L. em. Thell.). Asian J. Plant Sci. 10:190-201.

Suzuki, Y., Y. Sano, K. Ise, U. Matsukura, N. Aoki, and H. Sato. 2008. A rice mutant with enhanced amylose content in endosperm without affecting amylopectin structure. Breed. Sci. 58:209-215.

Tantasawat, P.A., A. Khairum, K. Arsakit, O. Poolsawat, P. Pornbungkerd, and C. Kativat. 2015. Effects of culture media on growth and proliferation of 'Earsakul' Dendrobium protocorm-like bodies. HortTechnology 25:681-686.

Tantasawat, P., J. Trongchuen, T. Prajongjai, W. Seehalak, and Y. Jittayasothorn. 2010a. Variety identification and comparative analysis of genetic diversity in yardlong bean (Vigna unguiculata spp. sesquipedalis) using morphological characters, SSR and ISSR analysis. Sci. Hort. 124:204-216.

Tantasawat, P., J. Trongchuen, T. Prajongjai, T. Thongpae, C. Petkhum, W. Seehalak, and T. Machikowa. 2010b. Variety identification and genetic relationships of mungbean and blackgram in Thailand based on morphological characters and ISSR analysis. Afr. J. Biotechnol. 9:4452-4464.

Tar'an, B., C. Zhang, T. Warkentin, A. Tullu, and A. Vandenberg. 2005. Genetic diversity among varieties and wild species accessions of pea (Pisum sativum L.) based on molecular markers, and morphological and physiological characters. Genome 48:257-272.

Türkan, A.D., K.M. Khawar, C.Y. Çiftçi, and S. Özcan. 2006. Effects of mutagenic sodium azide $\left(\mathrm{NaN}_{3}\right)$ on in vitro development of four pea (Pisum sativum L.) cultivars. Intl. J. Agr. Biol. 8:349-351.

Velemínský, J., T. Gichner, and V. Pokorný. 1977. Induction of DNA single-strand breaks in barley by sodium azide applied at $\mathrm{pH} 3$. Mutat. Res. 42:65-70.

Wang, H.Z., S.G. Feng, J.J. Lu, N.N. Shi, and J.J. Liu. 2009a. Phylogenetic study and molecular identification of 31 Dendrobium species using inter-simple sequence repeat (ISSR) markers. Sci. Hort. 122:440-447.

Wang, H.Z., Z.X. Wu, J.J. Lu, N.N. Shi, Y. Zhao, Z.T. Zhang, and J.J. Liu. 2009b. Molecular diversity and relationships among Cymbidium goeringii cultivars based on inter-simple sequence repeat (ISSR) markers. Genetica 136:391-399.

Wannajindaporn, A., O. Poolsawat, W. Chaowiset, and P.A. Tantasawat. 2014. Evaluation of genetic variability in in vitro sodium azide-induced Dendrobium 'Earsakul' mutants. Genet. Mol. Res. 13:5333-5342.

Xi, M., L. Sun, S. Qiu, J. Liu, J. Xu, and J. Shi. 2012. In vitro mutagenesis and identification of mutants via ISSR in lily (Lilium longiflorum). Plant Cell Rpt. 3:115-120.

Yao, X.H., L. Gao, and B. Yang. 2007. Genetic diversity of wild Cymbidium goeringii (Orchidaceae) populations from Hubei based on intersimple sequence repeats analysis. Front. Biol. China 2:419-424.

Yoocha, T., C. Chunwongse, and J. Chunwongse. 2006. Study of genetic relationship among commercial Dendrobium using microsatellite markers. Agr. Sci. J. 37:163-174.

Zhang, B.H. 2000. Regulation of plant growth regulators on cotton somatic embryogenesis and plant regeneration. Biochemistry 39:1567.

Zhang, F., Y. Lv, H. Dong, and S. Guo. 2010. Analysis of genetic stability through intersimple sequence repeats molecular markers in micropropagated plantlets of Anoectochilus formosanus Hayata, a medicinal plant. Biol. Pharm. Bull. 33:384-388.

Zhang, M.B., L.J. Pan, G.Q. Fan, and P. Cheng. 2009. Study on DNA isolation from polysaccharidesrich transgenic Dendrobium. Mol. Plant Breed. 7:209-214. 